\title{
In intra-articular distal humeral fractures: Can combined medial-lateral approach gain better outcomes than olecranon osteotomy?
}

\author{
(단 Libiao Wei, M.D., ${ }^{1}$ () Haitao Xu, M.D., ${ }^{2}$ (ㄴ) Zhiquan An, M.D. ${ }^{2}$ \\ ${ }^{1}$ Huadong Hospital Affiliated to Fudan University, Shanghai-China \\ 2Department of Traumatic Orthopedics Surgery, Shanghai Jiao Tong University Affiliated Sixth People's Hospital, Shanghai-China
}

\begin{abstract}
BACKGROUND: This research aimed to evaluate the functional outcomes of intra-articular distal humeral fractures treated through a combined medial-lateral approach and comparing with olecranon osteotomy simultaneously.
\end{abstract}

METHODS: In this study, 62 distal humeral fractures patients were assessed retrospectively. The olecranon osteotomy was used in 30 cases ( 14 males, 16 females) and combined medial-lateral in 32 cases ( 15 males, 17 females). The outcomes of function were assessed by the Mayo Elbow Performance Score (MEPS) and the Disabilities of Arm, Shoulder and Hand (DASH) questionnaire score. The follow-up time was $15.4 \pm 3.5$ months (range 10-24 months) for a combined medial-lateral group and 14.6 \pm 2.6 months (range 10-20 months) for olecranon osteotomy. Level of Evidence: Level, retrospective study.

RESULTS: The flexion-extension of elbows was $115.3^{\circ} \pm 16.1^{\circ}$ in the combined medial-lateral group, and the olecranon osteotomy group was $110.1^{\circ} \pm 15.2^{\circ}$. A significant difference was observed between the two groups for flexion-extension of the elbows $(p=0.04 \mathrm{I})$. Pronation-supination of the forearms had a significant difference $(p=0.025)$ between the combined medial-lateral group $\left(160.6^{\circ} \pm 7.2^{\circ}\right)$ and the olecranon osteotomy group $\left(154.1^{\circ} \pm 9.3^{\circ}\right)$. Mean MEPS, DASH, excellent and good rate and complication rate for combined medial-lateral approaches were $88.6 \pm 6.9$ points, $9.8 \pm 6.6$ points, $90.6 \%$ and $9.4 \%$, respectively. Significant differences were not noted between the two groups for mean MEPS, DASH scores and excellent and good rate $(p=0.594, p=0.505, p=0.934$, respectively) except complication rate $(p=0.005)$.

CONCLUSION: The combined medial-lateral approach is successful approach in the treatment of intra-articular distal humeral fractures (especially type $\mathrm{Cl}$ and $\mathrm{C2}$ ) that provides better outcomes for the motion of the elbow, bleeding volume in surgery and complications than olecranon osteotomy.

Keywords: Combined medial-lateral approach; complication; distal humerus; functional outcomes; olecranon osteotomy; surgical approach.

\section{INTRODUCTION}

The distal humeral fractures take up $1-7 \%$ of all fractures and constitute $30 \%$ of all elbow fractures. The distal humeral fractures are clinically difficult to manage, especially the intraarticular fracture. The favorite treatment for intra-articular distal humeral fractures is open reduction and internal fixation (ORIF). In the past 20 years, many studies have suggested that operation provides satisfactory clinical and radiographic effects. Anatomic reconstruction of the articular surface and stable internal fixation are key factors of the excellent functional effects. ${ }^{[I]}$ To have a good anatomic reduction and stable internal fixation, it is essential to gain enough exposure to the articular surface. ${ }^{[2]}$ Many surgical approaches are used in operation to have excellent exposure, which includes olecranon osteotomy, triceps-reflecting anconeus pedicle (TRAP),

Cite this article as: Wei L, Xu H, An Z. In intra-articular distal humeral fractures: can combined medial-lateral approach gain better outcomes than olecranon osteotomy?. Ulus Travma Acil Cerrahi Derg 2020;26:586-592.

Address for correspondence: Zhiquan An, M.D.

Shanghai Jiao Tong University Affiliated Sixth People's Hospital, 600 Yishan Road, Shanghai 200233 Shanghai, China

Tel: 18930177455 E-mail: zhiquan_an@I63.com

Ulus Travma Acil Cerrahi Derg 2020;26(4):586-592 DOI: 10.14744/tjtes.2019.69486 Submitted: 08.04.2019 Accepted: 07.12.2019 Online: 24.06.2020

Copyright 2020 Turkish Association of Trauma and Emergency Surgery 
triceps splitting, Bryan-Murrey (triceps reflecting), extensor mechanism-sparing paratricipital posterior approach and combined medial-lateral approach.

Olecranon osteotomy approach is still used the most frequently in the operation because of its adequate exposure. ${ }^{[3]}$ However, it also has many disadvantages, such as nonunion, delayed union, heterotrophic ossification and ulnar nerve paralysis. ${ }^{[3,4]}$ The combined medial-lateral approach combines two different approaches, including medial and lateral of the elbow joint, which can provide good exposure of articular surface, avoid the osteotomy and the less complication. ${ }^{[5]}$

The indications and advantages of the combined medial-lateral approach are lack of literature reports, and there is not any comparison about the two surgical techniques in related literature. Therefore, this research aims to evaluate the functional outcomes of intra-articular distal humeral fractures treated through a combined medial-lateral approach and comparing with olecranon osteotomy simultaneously.

\section{MATERIALS AND METHODS}

In this study, 62 patients who were diagnosed as intra-articular distal humeral fractures by AO/ASIF classification and treated by ORIF were retrospectively evaluated from 2014 to 2017. This research was allowed by the Medical Ethical Committee of the author's institution and was proceeded according to the ethical standards of the 1964 Declaration of Helsinki and later amendments. The combined medial-lateral approach was performed in 32 patients and olecranon osteotomy in 30 patients. Sex and age were no tendencies totally according to statistics, and the fracture classification and time from hurt to surgery did not have any tendency, too (all p>0.05) (Table I). The exclusion criteria were as follows: pathologic fractures, pediatric fractures, functional loss due to other diseases, open fractures, scanty follow-up time and who cannot endure surgery because of other issues.

The cause of injury included 15 cases of fall, eight cases of machinery-related trauma, six cases of traffic injury and three cases of sports injury in the combined medial-lateral group, and 14 cases of fall, 10 cases of traffic injury, four cases of machinery-related trauma and two cases of sport injury in olecranon osteotomy group.

\section{Surgical Technique}

The whole patients were performed in supine or lateral position and tourniquet was utilized. The whole operations were handled under general anesthesia or blockade of the brachial plexus.

In the combined medial-lateral group, the patient stayed supine position and the injured arm was put at $90^{\circ}$ of abduction on the operating table. The first incision from medial epicondyle to proximal humerus about $7 \mathrm{~cm}$ with the elbow flexed about $60^{\circ}$ was begun. The distal humeral medial and

Table I. Data summary of the patients $($ mean $\pm S D)$

\begin{tabular}{|c|c|c|c|}
\hline Parameters & $\begin{array}{l}\text { Combined medial-lateral } \\
\qquad(n=32)\end{array}$ & $\begin{array}{l}\text { Olecranon osteotomy } \\
\qquad(n=30)\end{array}$ & $\mathbf{p}^{*}$ \\
\hline Male/female ratio (no. of patients) & $15 / 17$ & $14 / 16$ & 0.987 \\
\hline Age (year) (range) & $43.8 \pm 17.7(18-73)$ & $44.1 \pm 17.0(18-70)$ & 0.815 \\
\hline Time from hurt to surgery (day) & $2.9 \pm 1.1$ & $2.9 \pm 0.9$ & 0.789 \\
\hline Time of surgery (hour) & $2.3 \pm 0.6$ & $2.5 \pm 0.7$ & 0.833 \\
\hline Bleeding volume in surgery $(\mathrm{mL})$ & $|28| \pm 34.2$. & $211.3 \pm 40.3$ & 0.001 \\
\hline Healing time of fracture (week) (range) & $|5.3 \pm 2|.(9-2 \mid)$ & $14.9 \pm 3.5(9-20)$ & 0.259 \\
\hline Follow-up time (month) (range) & $15.4 \pm 3.5(10-24)$ & $14.6 \pm 2.6(10-20)$ & 0.098 \\
\hline AO/ASIF classification (no. of patients) & & & 0.797 \\
\hline $\mathrm{Cl}$ & 14 & 12 & \\
\hline $\mathrm{C} 2$ & 17 & 16 & \\
\hline $\mathrm{C} 3$ & 1 & 2 & \\
\hline \multicolumn{4}{|l|}{ The gap in the main articular fragments } \\
\hline (no. of patients) & & 0.623 & \\
\hline$<1 \mathrm{~mm}$ & 29 & 26 & \\
\hline$>1 \mathrm{~mm}$ & 3 & 4 & \\
\hline Complication rate (\%) & 9.4 & 40 & 0.005 \\
\hline
\end{tabular}


anteromedial side was exposed through the incision between the brachial muscle and the medial intermuscular septum. The ulnar nerve was exposed behind the medial intermuscular septum but not isolated. Then, the flexor muscles were dissected partially and turned up distally, leaving a 5 $\mathrm{mm}$ strut to be re-sutured in situ after the surgery. With the anterior capsule cut, the front of the trochlea part and medial epicondyle were exposed. Another incision was initiated from the lateral epicondyle to proximal humerus about $8 \mathrm{~cm}$. The space between the posterior triceps, the origins of the extensor carpi radialis longus, the anterior brachioradialis and the anterior distal humeral articular surface were exposed. The interspace between extensor carpi ulnaris and the anconeus was cut, and the articular surface of the humeral capitulum and the lateral humeral trochlea were exposed. Then keeping the elbow flexed about $80^{\circ}$, the biceps brachii and brachialis were loosed anteriorly. The medial articular fragments were reduced to the medial column and fixed with K-wires temporally. Moreover, the small articular fragments were reduced to the main lateral fragments and fixed with $\mathrm{K}$-wires. The main lateral articular fragments were to be reduced to the medial articular fragments of closing to the lateral column and held with $\mathrm{K}$-wires temporarily. The reduction of the articular surface was collated under the direct sight and the C-arm. When the articular fracture fragments were reduced anatomically, a $1.25-\mathrm{mm}$ guidewire was inserted into the humeral trochlea from lateral condyle to medial condyle then checked by $\mathrm{C}$-arm. Articular surface fracture fragments were fixed by a $4.0-\mathrm{mm}$ cannulated screw inserted through the guidewire. If the articular surface of the distal humerus was reduced anatomically, the medial and lateral column could be fixed with two reconstruction plates and some screws. Finally, the dissected flexor muscles were repaired, and the incisions were sutured (Fig. I).
In the olecranon osteotomy group, the patient was placed in a lateral position with the arm supported over a bolster. Either the prior incision or a straight posterior incision was used. Medial and lateral skin flaps were elevated, with care taken to protect cutaneous nerve branches and keep them within the skin flaps. The ulnar nerve was recognized by the medial border of the triceps, dissected at least $6 \mathrm{~cm}$ proximally and distally, and left in an anteriorly transposed position in the subcutaneous tissues. An apex distal, chevron-shaped osteotomy was performed then. The osteotomy was proceeded about $2 \mathrm{~cm}$ distal to the tip of the olecranon. An oscillating or fret saw was used to begin the osteotomy. The posterior elbow capsule was dissected, and the distal humeral articular surface was exposed. The distal humeral fractures fragments were reduced then fixed by K-wires temporarily. While reaching the anatomical reduction, the double plates were used to fix the fracture fragments. The fragment of olecranon osteotomy was restored and fixed by using a tension band and two K-wires. The elbow was then put by a full range of motion to assess the safety of fixation. If the fixation was stable enough, the wound was closed.

\section{Postoperative Care}

Early functional exercise began once the patient's pain was under control. Indomethacin was advised to prevent possible myositis ossificans for one month. The drainage tube was removed I-2 days postoperatively. Changing a medical prescription was performed once every two days and taking out stitches time was approximately two weeks postoperatively.

\section{Follow-up}

Patients were followed up for once everyone and half months in the first three months, then once every three months until the fracture reached union. After fracture got a union, it was
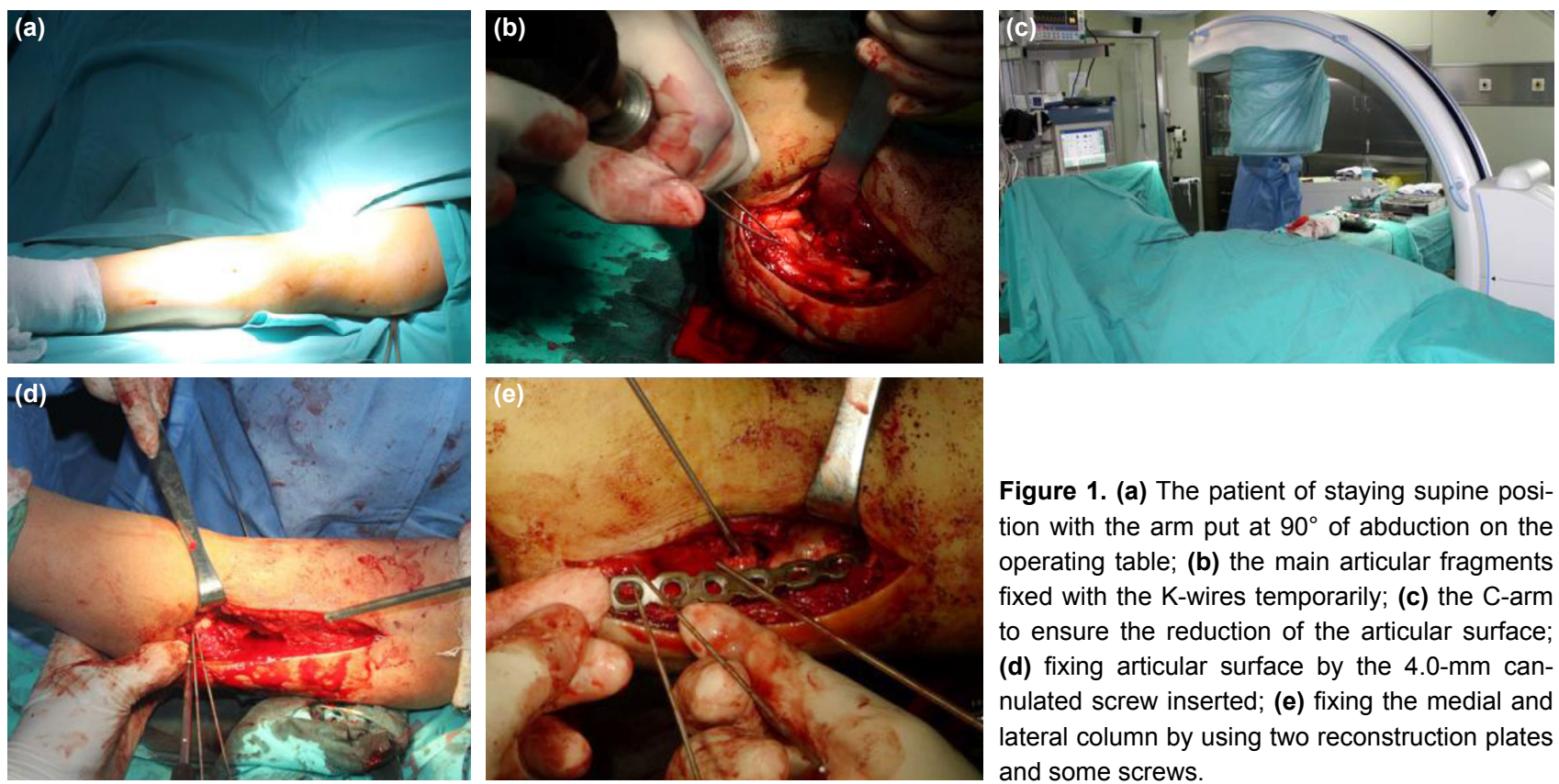

Figure 1. (a) The patient of staying supine position with the arm put at $90^{\circ}$ of abduction on the operating table; (b) the main articular fragments fixed with the K-wires temporarily; (c) the C-arm to ensure the reduction of the articular surface; (d) fixing articular surface by the $4.0-\mathrm{mm}$ cannulated screw inserted; (e) fixing the medial and lateral column by using two reconstruction plates and some screws. 
once every six months up to one year. The gaps in the medial and lateral articular fragments were measured by a postoperative standard anteroposterior and lateral radiograph. The Caja scale was used to assess the reduction level of the distal humeral articular surface. ${ }^{[6]}$ The union standard was that the pain was absent, and the fracture lines of the metaphyseal district fragments and articular surface fragments were obscure. In the final follow-up, the functional assessment of the patients was performed in the motion of elbow and forearm, MEPS and DASH questionnaire.

\section{Statistical Analysis}

All data were analyzed using SPSS V20.0 and recorded by mean \pm standard deviation $( \pm S D)$. A p-value $<0.05$ indicated a significant difference.

\section{RESULTS}

In this study, the two aspects in mean follow-up time and healing time of fractures did not have significant differences between the two groups, and another significant difference was not observed for sex, age, time from hurt to surgery, time of surgery and sort of fractures (all $\mathrm{p}>0.05$ ). However, bleeding volume in surgery between the two groups had a significant difference $(p=0.00 \mathrm{I})$ (Table I).
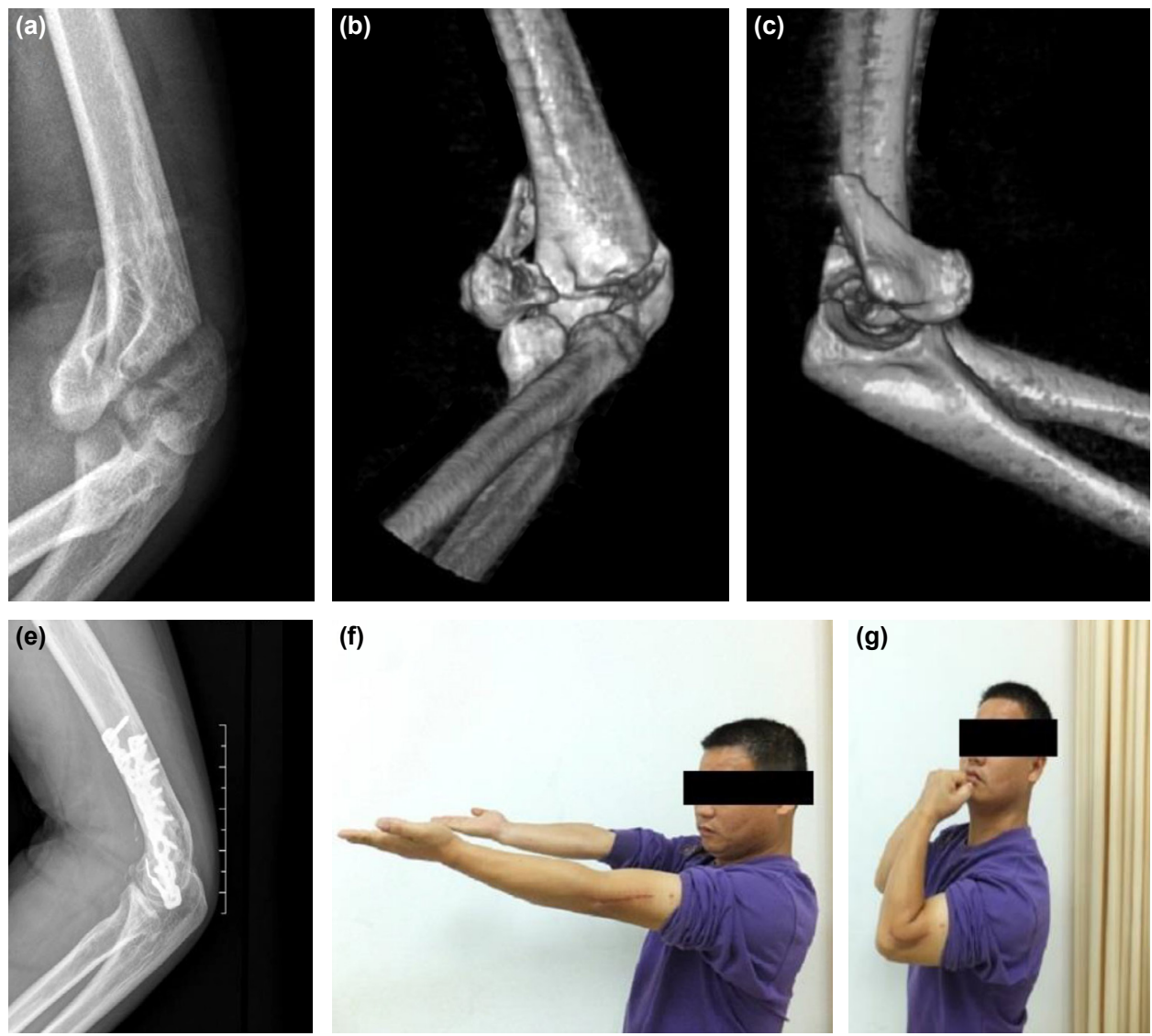

(f)

(g)
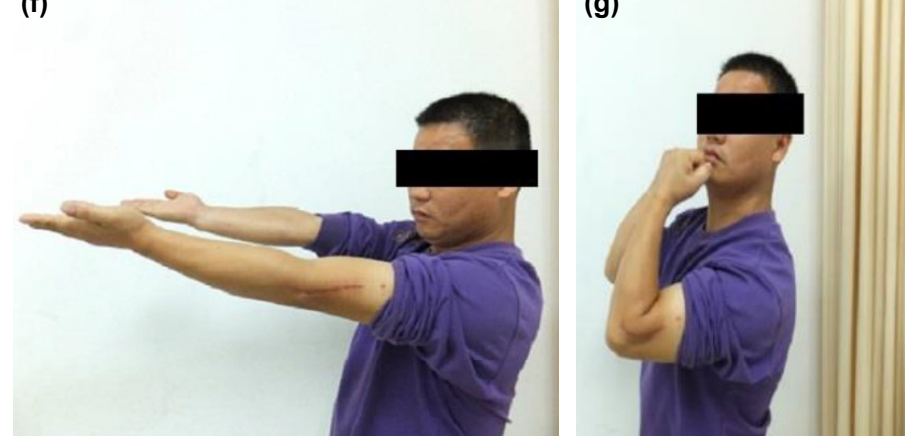

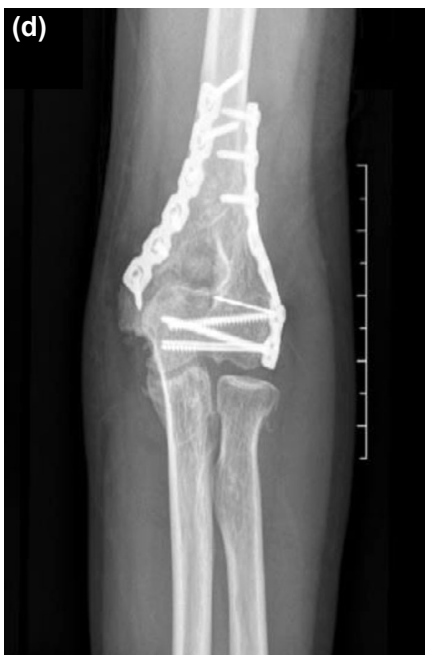

(h)

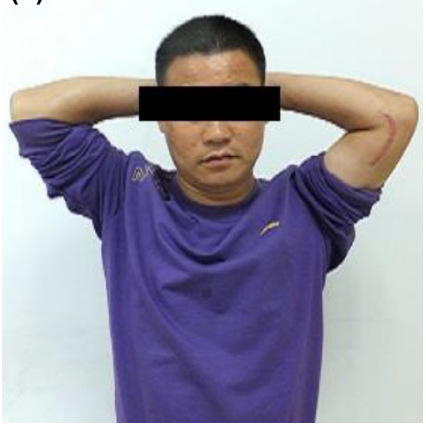

Figure 2. Preoperative X-rays and CT of the elbow showing the intra-articular distal humeral fracture (a-c); after double plates fixation using the combined medial-lateral approach, in 13 months of follow-up, X-rays showing fracture union (d, e); functional view of the patient (f-h). 

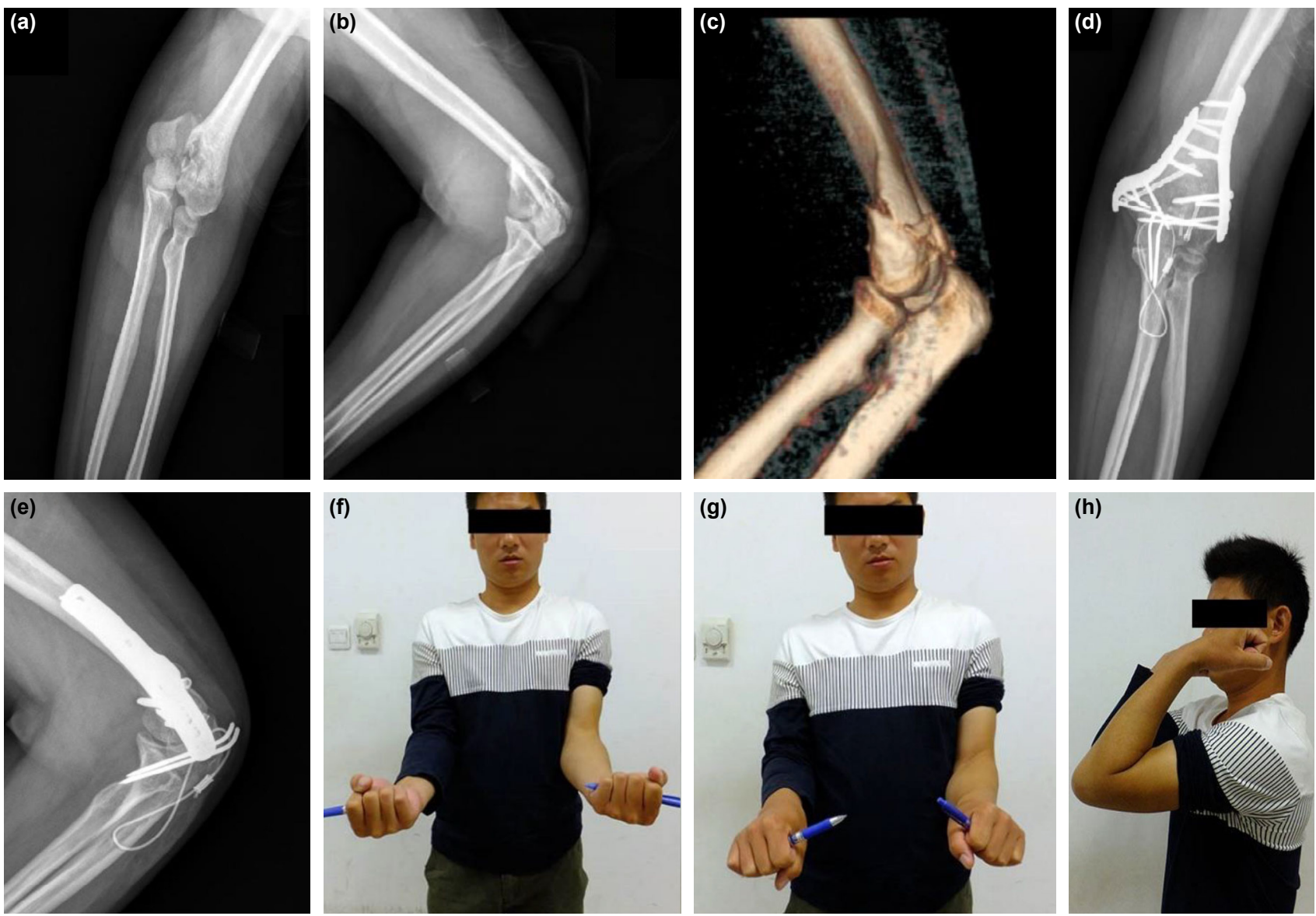

Figure 3. (a-c) Preoperative X-rays and CT of the elbow showing the intra-articular distal humeral fracture; (d, e) after double plates fixation using olecranon osteotomy, in 10 months of follow-up, X-rays showing fracture union; (f-h) functional view of the patient.

In the combined medial-lateral group, there was one case of traumatic arthritis after three months postoperatively who was relieved by celecoxib. One patient's incision was infected after three days postoperatively, and it was healed by dressing change and antibiotics. In one case, ulnar nerve paresthesia appeared, and it was relieved by mecobalamin, which is a drug of nerve nutrition. In the olecranon osteotomy group, there were eight cases of ulnar nerve paresthesia postoperatively, which were resolved by mecobalamin, vitamin $\mathrm{BI}$, vitamin B6 and functional exercise in three months. Infectious wounds were present in three patients, which were healed by dressing change and antibiotics. One patient developed joint stiffness after three months postoperatively, which was solved by elbow adhesiolysis eventually. There was a significant difference

Table 2. Arc of the elbow motion and functional outcomes (mean \pm SD)

\begin{tabular}{|c|c|c|c|}
\hline Parameters & $\begin{array}{l}\text { Combined medial-lateral } \\
\qquad(n=32)\end{array}$ & $\begin{array}{l}\text { Olecranon osteotomy } \\
\qquad(n=30)\end{array}$ & $\mathbf{p}^{*}$ \\
\hline Flexion-extension of the elbows (range) & $1|5.3 \pm 16|.(80-145)$ & $110.1 \pm 15.2(80-140)$ & 0.041 \\
\hline Pronation-supination of the forearms (range) & $160.6 \pm 7.2(140-180)$ & $154.1 \pm 9.3(140-175)$ & 0.025 \\
\hline DASH score & $9.8 \pm 6.6$ & $10.5 \pm 7.0$ & 0.505 \\
\hline MEPS score & $88.6 \pm 6.9$ & $85 . I \pm 5.4$ & 0.594 \\
\hline Excellent, (n) & II & 8 & \\
\hline Good, (n) & 18 & 19 & \\
\hline Fair, (n) & 3 & 3 & \\
\hline Poor, (n) & 0 & 0 & \\
\hline Excellent and good rate (\%) & 90.6 & 90.0 & 0.934 \\
\hline
\end{tabular}

${ }^{*} \mathrm{P}$-value $<0.05$ was indicated a significant difference. SD: Standard deviation. 
in the complication rate between the two groups $(p=0.005)$ (Table I), and the olecranon osteotomy group had a higher complication rate.

\section{DISCUSSION}

What is the best surgical pathway for exposure, reduction and fixation is presently still controversial. In this study, the findings suggest that the combined medial-lateral approach is more excellent than the olecranon osteotomy approach concerning the flexion-extension of the elbows, the pronationsupination of the forearms, bleeding volume in surgery and complication rate (all $\mathrm{p}<0.05$ ). While MEPS scores and DASH scores were performed, there was no significant difference based on SPSS V20.0 between the two groups $(p=0.594$, $\mathrm{p}=0.505$, respectively).

Olecranon osteotomy can provide the most extensive exposure of the distal humerus. Tak et al. ${ }^{[7]}$ demonstrated that olecranon osteotomy was used in the treatment of 94 cases of intra-articular distal humerus fractures that contained 30 (32\%) type $\mathrm{Cl}, 39$ (4l\%) type C2 and 25 (27\%) type C3 fractures with a mean follow-up of 24 months. The final follow-up indicated that $82(92 \%)$ patients had a range of motion elbow more than functional range, $80(90 \%)$ patients had the activity level equaling before the injury, and the excellent and good rate was up to $85.4 \%$. Even though the functional outcomes of elbow joint were well enough, the complication related to osteotomy could not be ignored, which included 23 (25.9\%) cases prominent olecranon screw, 17 (19.1\%) cases painful bursa over the screw head, 29 (32.6\%) cases secondary procedure for removal of symptomatic osteotomy fixation and 4 (4.5\%) cases delayed union. From the previous and our study, we can see that although olecranon osteotomy could provide enough exposure of articular surface and good effects, the conspicuous complication is still an intractable issue, such as delayed union, nonunion, implant removal and so on.

Xie et al. ${ }^{[5]}$ reported that using a combined medial-lateral approach treated 19 patients ( 4 of $\mathrm{Cl}, 12$ of $\mathrm{C} 2,3$ of $\mathrm{C} 3$ ) with follow-up of $15.8 \pm 7.9$ (range 7-43) months. At the final follow-up, the mean flexion-extension was $113.4^{\circ} \pm 20.7^{\circ}$, the pronation-supination of the forearms was $158.3^{\circ} \pm 8.5^{\circ}$, and the mean MEPS score was $93.7 \pm 9.1$ points, including $13 \mathrm{ex}$ cellent and six good cases (excellent or good rates $100 \%$ ). According to postoperative $X$-rays and the Caja rating system, 16 cases achieved anatomical reduction, 15 cases scored 20 , and four cases scored 15 points. X-rays demonstrated that all the fractures were union with a mean healing time of I4.I \pm 3.0 (range 8-20) weeks. Myositis ossificans happened to one patient and periprosthetic fracture also to one (10.5\%) among the whole patients. Our results are similar to the report that had great outcomes of the elbow and low complication rate. Although the combined medial-lateral approach is rarely reported in the literature, the effects of the approach are noticeable and excellent in this study. The combined medi- al-lateral approach can keep integrality of the elbow extensor and therefore, does not influence the extension power, which can make patients exercise early. Similar to other surgical approaches, the exposed articular surface of the combined medial-lateral approach is limited and the major exposed district is in front of the distal humeral articular surface. In our unpublished anatomic research article, it shows that the combined medial-lateral approach can expose $46.9 \%$ of the distal humeral articular surface, which can provide enough exposure to reduce and fix the fracture fragments.

This study also has several limitations. Firstly, this is a retrospective study. The data of patients cannot be controlled by us, and the choice of patients is not randomized so that a bias exists that we cannot avoid. Secondly, the number of patients is not very average, and the majority is type $\mathrm{Cl}$ and $C 2$, and $C 3$ is few although there were no significant differences totally for sex, age and classification according to statistics (both $p>0.05$ ). Thirdly, we cannot compare with subgroups of the distal humerus fractures, such as comminuted, osteoporotic and osteoarthritis fractures. Future studies should comprise homogeneous sub-group types, specific age groups with a similar degree of osteoporotic bone, which can demonstrate more exact results for surgical indications and effects of combined medial-lateral approach and olecranon osteotomy.

\section{Conclusion}

From the comparison of our study, the combined medial-lateral approach is a successful approach in the treatment of intra-articular distal humerus fractures (especially type $\mathrm{Cl}$ and $\mathrm{C} 2$ ) that provides better outcomes for the motion of elbow, bleeding volume in surgery and complications than olecranon osteotomy.

\section{Acknowledgements}

The authors declare that they have no competing interests, and all authors have confirmed its accuracy. This study is supported by the fund of the hospital-level project (LYZY-0I42).

Ethics Committee Approval: Approved by the local ethics committee.

\section{Peer-review: Internally peer-reviewed.}

Conflict of Interest: None declared.

\section{REFERENCES}

1. Gupta R, Khanchandani P. Intercondylar fractures of the distal humerus in adults: a critical analysis of 55 cases. Injury 2002;33:511-5. [CrossRef]

2. Hausman M, Panozzo A. Treatment of distal humerus fractures in the elderly. Clin Orthop Relat Res 2004;425:55-63. [CrossRef]

3. Chen G, Liao Q, Luo W, Li K, Zhao Y, Zhong D. Triceps-sparing versus olecranon osteotomy for ORIF: analysis of 67 cases of intercondylar fractures of the distal humerus. Injury 2011;42:366-70. [CrossRef]

4. Li SH, Li ZH, Cai ZD, Zhu YC, Shi YZ, Liou J, et al. Bilateral plate fixa- 
tion for type $\mathrm{C}$ distal humerus fractures: experience at a single institution. Int Orthop 2011;35:433-8. [CrossRef]

5. Xie X, Qin H, Shen L, Zeng B, An Z. Open reduction and bi-columnar internal fixation of intra-articular distal humerus fractures through a combined medial and lateral approach. Eur J Orthop Surg Traumatol 2014;24:1115-22. [CrossRef]
6. Caja VL, Moroni A, Vendemia V, Sábato C, Zinghi G. Surgical treatment of bicondylar fractures of the distal humerus. Injury 1994;25:433-8.

7. Tak SR, Dar GN, Halwai MA, Kangoo KA, Mir BA. Outcome of olecranon osteotomy in the trans-olecranon approach of intra-articular fractures of the distal humerus. Ulus Travma Acil Cerrahi Derg 2009;15:565-70.

\section{ORIJIINAL ÇALIŞMA - ÖZET}

\section{İntraartiküler distal humerus kırıklarında: Kombine mediolateral yaklaşım olekranon osteotomisinden daha iyi sonuçlar elde edilmesini sağlayabilir mi? \\ Dr. Libiao Wei, ${ }^{1}$ Dr. Haitao Xu, ${ }^{2}$ Dr. Zhiquan $\mathrm{An}^{2}$}

${ }^{1}$ Fudan Üniversitesi Huadong Hastanesi, Şangay-Çin

${ }^{2}$ Shanghai Jiao Tong Üniversitesi Altıncı Halk Hastanesi, Ortopedi ve Travmatoloji Anabilim Dalı, Şangay-Çin

AMAÇ: Araştırma, kombine mediolateral yaklaşımla tedavi edilen intraartiküler distal humerus kırıklarının fonksiyonel sonuçlarını değerlendirmeyi ve eş zamanlı olarak olekranon osteotomisi ile karşılaştırmayı amaçlamaktadır.

GEREÇ VE YÖNTEM: Altmış iki distal humerus kırığı geriye dönük olarak incelendi. Otuz olguda ( 14 erkek, 16 kadın) olekranon osteotomisi ve 32 olguda kombine mediolateral ( 15 erkek, 17 kadın) yaklaşım kullanıldı. Fonksiyonel sonuçlar Mayo Dirsek Performans Skoru (Mayo Elbow Performance Score: MEPS) ve Kol, Omuz ve El Sakatlıkları (Disabilities of Arm, Shoulder and Hand: DASH) anket skoru ile değerlendirildi. Takip süreleri kombine mediolateral yaklaşım grubu için 15.4 \pm 3.5 ay (10-24 ay) ve olekranon osteotomisi için ise 14.6 \pm 2.6 ay (10-20 ay) idi.

BULGULAR: Dirseklerin fleksiyon-ekstansiyonu kombine mediolateral grupta $115.3^{\circ} \pm 16.1^{\circ}$ ve olekranon osteotomisi grubunda $110.1^{\circ} \pm 15.2^{\circ}$ idi. Dirseklerin fleksiyon-ekstansiyonu açısından iki grup arasında anlamlı bir fark gözlendi $(p=0.04 \mathrm{I})$. Önkolların pronasyon-supinasyonu açısından kombine mediolateral grup $\left(160.6^{\circ} \pm 7.2^{\circ}\right)$ ile olekranon osteotomisi grubu $\left(154.1^{\circ} \pm 9.3^{\circ}\right)$ arasında anlamlı bir fark gözlenmedi $(p=0.025)$. Kombine mediolateral yaklaşımlar için ortalama MEPS, DASH skorlarına göre mükemmel -iyi sonuç puanları ve komplikasyon oranları sırasıyla $88.6 \pm 6.9$ puana karşın $9.8 \pm 6.6$ puan ve \%90.6'ya karşın \%9.4 idi. İki grup arasında komplikasyon oranı $(p=0.005)$ dışında ortalama MEPS, DASH skorları ve mükemmel ve iyi oranlar (sırasıyla $p=0.594, p=0.505, p=0.934$ ) arasında önemli farklılıklar görülmemiştir.

TARTIŞMA: Kombine mediolateral yaklaşım, intraartiküler distal humerus kırıklarının (özellikle tip CI ve C2) tedavisinde dirsek hareketi, ameliyattaki kanama hacmi ve komplikasyonlar açısından olekranon osteotomisine göre daha iyi sonuçlar veren başarılı bir yaklaşımdır.

Anahtar sözcükler: Cerrahi yaklaşım; distal humerus; fonksiyonel sonuçlar; kombine mediolateral yaklaşım; komplikasyon; olekranon osteotomisi.

Ulus Travma Acil Cerrahi Derg 2020;26(4):586-592 doi: 10.14744/tjtes.2019.69486 